\title{
aHIF but not HIF-1 $\alpha$ transcript is a poor prognostic marker in human breast cancer
}

\author{
Anne Cayre ${ }^{1}$, Fabrice Rossignol ${ }^{2}$, Eric Clottes $^{2}$ and Frédérique Penault-Llorca ${ }^{1}$ \\ ${ }^{1}$ Department of Pathology and INSERM U484, Centre Jean Perrin, Clermont-Ferrand, France \\ ${ }^{2}$ Laboratoire Inter-Universitaire de Biologie des Activités Physiques et Sportives, Faculté de Médecine, Clermont-Ferrand, France \\ Corresponding author: Anne Cayre (e-mail: anne.cayre@cjp.fr)
}

Received: 14 Mar 2003 Revisions requested: 15 May 2003 Revisions received: 16 Jun 2003 Accepted: 28 Aug 2003 Published: 26 Sep 2003

Breast Cancer Res 2003, 5:R223-R230 (DOI 10.1186/bcr652)

(C) 2003 Cayre et al., licensee BioMed Central Ltd (Print ISSN 1465-5411; Online ISSN 1465-542X). This is an Open Access article: verbatim copying and redistribution of this article are permitted in all media for any purpose, provided this notice is preserved along with the article's original URL.

\begin{abstract}
Background: Hypoxia-inducible factor- $1 \alpha(\mathrm{HIF}-1 \alpha)$ is part of a transcriptional factor that regulates genes involved in metabolic and vascular adaptation of tumours to oxygen restriction. A splicing variant lacking exon 14 (sHIF- $1 \alpha$ ) encodes a truncated protein that competes with the normal HIF-1 $\alpha$ protein, decreasing its activity. A natural antisense transcript (aHIF) complementary to the $3^{\prime}$-untranslated region of HIF- $1 \alpha$ mRNA was described recently.
\end{abstract}

Methods: With a semiquantitative multiplex reverse transcriptase-PCR (RT-PCR) assay, we assessed transcript concentrations of HIF- $1 \alpha$, sHIF- $1 \alpha$ and aHIF in 110 patients with invasive breast carcinoma.

Results: We found a strong positive association between HIF- $1 \alpha$ and sHIF- $1 \alpha$, sHIF- $1 \alpha$ and aHIF, and an inverse correlation between HIF- $1 \alpha /$ sHIF- $1 \alpha$ and aHIF. aHIF transcript expression was associated with poor disease-free survival in univariate $(P=0.0038)$ and multivariate $(P=0.0016)$ analyses in this series of high-risk primary breast carcinomas.

Conclusion: In our series of breast cancer patients, aHIF, and not HIF- $1 \alpha$ transcript, is a marker of poor prognosis.

Keywords: breast cancer, HIF- $1 \alpha$, HIF- $1 \alpha$ natural antisense, HIF- $1 \alpha$ splicing

\section{Introduction}

Tumour cells generally grow in a hypoxic environment. They have to adapt their metabolism to the low availability of oxygen by increasing glucose transport and glycolysis to conserve sufficient ATP production. They also have to trigger angiogenesis by producing angiogenic factors such as vascular endothelial growth factor to facilitate their vascularisation and to improve their oxygen supply. These two adaptations are made possible by gene regulation under the control of the transcription factor hypoxiainducible factor-1 (HIF-1) [1].

HIF-1 is a heterodimer made up of two subunits, HIF- $1 \alpha$ and HIF-1 $\beta$ (also called aryl hydrocarbon receptor nuclear translocator, or ARNT). The HIF-1 $\beta$ protein is expressed constitutively, whereas HIF- $1 \alpha$ protein is not detectable in cells under normoxic conditions although its coding mRNA can be present [1]. In normoxia, the absence of HIF- $1 \alpha$ protein is due to proteasomal degradation by means of the von Hippel-Lindau tumour suppressor protein [1].

Although HIF-1 $\alpha$ protein regulation has been well studied [1], it is only lately that HIF-1 $\alpha$ messenger regulation has started to be documented [2]. Full-length HIF-1 $\alpha$ mRNA contains 15 exons, and a recent study has shown the existence of a splicing variant of HIF- $1 \alpha$ mRNA lacking exon 14 (sHIF-1 $\alpha$ ). The truncated HIF-1 $\alpha$ protein obtained

aHIF = hypoxia-inducible factor $1 \alpha$ natural antisense; $b p=$ base pairs; DFS = disease-free survival; dNTP = deoxyribonucleotide triphosphate; HIF-1 = hypoxia-inducible factor 1 ; IDC = invasive ductal carcinoma; ILC = invasive lobular carcinoma; REx = relative expression; RT = reverse transcription; SBR $=$ Scarff, Bloom and Richardson; sHIF-1 $\alpha=$ HIF-1 $\alpha$ splice variant. 
from this shorter mRNA is able to compete with the normal HIF- $1 \alpha$ protein for HIF-1 $\beta$ and therefore to decrease HIF-1 transcriptional activity [3].

A natural antisense transcript (aHIF) complementary to the $3^{\prime}$-untranslated region of HIF-1 $\alpha$ mRNA has been described [4]. This sequence, which does not encode any protein, is expressed in numerous human fetal and adult tissues and in some tumours [5]. Expression of aHIF transcripts might be involved in HIF- $1 \alpha$ mRNA regulation and therefore in HIF-1 $\alpha$ protein synthesis.

Breast carcinoma is the most common cancer in women. HIF- $1 \alpha$ is considered to be a reliable prognostic and diagnostic marker for an increasing number of cancers from various origins [6]. The aim of our study was to measure correlations in vivo between HIF- $1 \alpha$ mRNA, sHIF- $1 \alpha$ and $\mathrm{aHIF}$, and to determine whether the concentrations of these transcripts are associated with prognosis in human breast cancer.

\section{Materials and methods Patients}

One hundred and ten patients with previously untreated primary invasive breast carcinoma were included in this retrospective study. Initial staging comprised complete and detailed clinical examination including the International Union Against Cancer TNM (tumour size, nodes, metastases) classification [7]. Ultrasound examination and bilateral mammography were also performed. Histopathological evaluation of the tumours was performed on core needle biopsies by Scarff, Bloom and Richardson (SBR) grading as modified by Elston and Ellis [8]. One sample for each patient was used for DNA analysis by flow cytometry with EPICS V (Beckman-Coulter, Roissy, France). Tumour characteristics are reported in Table 1.

Under French law on biomedical research, this is an epidemiological study that does not have to be submitted to an Institutional Review Board.

\section{Treatments}

After biopsy, all patients received neoadjuvant anthracyclinebased chemotherapy with doxorubicin $\left(30-50 \mathrm{mg} / \mathrm{m}^{2}\right.$ at day 1$)$, pirarubicin $\left(20 \mathrm{mg} / \mathrm{m}^{2}\right.$ at days 1 to 3 ) or epirubicin $\left(35-100 \mathrm{mg} / \mathrm{m}^{2}\right.$ at day 1$)$, for six courses, the interval between each course being 3 weeks. After induction chemotherapy, patients underwent surgery, radiotherapy and adjuvant tamoxifen for patients with oestrogen receptors.

\section{Expression of HIF-1 $\alpha$, SHIF- $1 \alpha$ and aHIF- $1 \alpha$}

Fine-needle aspirates were performed in 110 patients diagnosed for breast cancer. An aliquot of each aspirate was smeared on a slide to serve as a control, by a pathologist, for the presence of malignant cells and the absence stored in liquid nitrogen until RNA extraction. Total RNA was extracted with Trizol reagent (Gibco/BRL, Cergy-Pontoise, France). RNA was then stored at $-80^{\circ} \mathrm{C}$ until cDNA synthesis and amplification reaction. Reverse transcription (RT) was performed at $42^{\circ} \mathrm{C}$ for $30 \mathrm{~min}$ in a $20 \mu$ reaction mixture containing RNA, $1 \mu$ l of each deoxyribonucleotide triphosphate (dNTP) at $25 \mathrm{mM}$ (Gibco/BRL), $2 \mu \mathrm{l}$ of $10 x$ reaction buffer $\left(67 \mathrm{mM} \mathrm{MgCl}, 166 \mathrm{mM}\left(\mathrm{NH}_{4}\right)_{2} \mathrm{SO}_{4}\right.$, $670 \mathrm{mM}$ Tris- $\mathrm{HCl}$ at $\mathrm{pH} 8.8), 1 \mu \mathrm{l}$ of $\mathrm{PdN} 6$ random hexamers $(100 \mu \mathrm{M}$; Roche, Meylan, France) and $200 \mathrm{U}$ of $\mathrm{Mu}$ MLV reverse transcriptase (Gibco/BRL). RT products were diluted 1:25. Semiquantitative determination of HIF- $1 \alpha$, sHIF- $1 \alpha$ and aHIF transcript concentrations were performed by RT-PCR with $\beta_{2}$-microglobulin $\left(\beta_{2}\right)$ as an internal control sequence. Each PCR reaction was performed in a $50 \mu \mathrm{l}$ containing $5 \mu \mathrm{l}$ of the diluted RT product, $0.5 \mu \mathrm{l}$ of $25 \mathrm{mM}$ dNTPs, $5 \mu \mathrm{l}$ of $10 \times$ buffer II containing $15 \mathrm{mM} \mathrm{MgCl} 2$ (Applied Biosystems, Courtaboeuf, France), $1.25 \mathrm{U}$ of AmpliTaq Gold (Applied Biosystems), $12.5 \mathrm{pmol}$ of HIF- $1 \alpha, 12.5 \mathrm{pmol}$ of aHIF and $25 \mathrm{pmol}$ each of $\beta_{2}$ forward and reverse primers. With HIF- $1 \alpha$ primers, two amplicons were obtained, one of 486 base pairs (bp) corresponding to HIF-1 $\alpha$ and one of $359 \mathrm{bp}$ corresponding to sHIF-1 $\alpha$. The primers used are described in Table 2. In preliminary experiments we determined the number of cycles that allowed the linear simultaneous amplification of the four different templates (up to 40 cycles). The optimised PCR program was $94^{\circ} \mathrm{C}$ for $10 \mathrm{~min}$, then 38 cycles of $94^{\circ} \mathrm{C}$ for $50 \mathrm{~s}, 60^{\circ} \mathrm{C}$ for $50 \mathrm{~s}$ and $72^{\circ} \mathrm{C}$ for $20 \mathrm{~s}$, followed by a final elongation step at $72^{\circ} \mathrm{C}$ for $10 \mathrm{~min}$. PCR reactions were run on a Masterblock Thermocycler (Eppendorf, Le Pecq, France). Each RT-PCR product $(15 \mu \mathrm{l})$ was loaded on a $6 \%$ polyacrylamide $(19: 1) \mathrm{gel}$ (QBiogen, Illkirch, France) and run for $3 \mathrm{~h}$ at $120 \mathrm{~V}$ in $1 \mathrm{x}$ Tris-borate-EDTA. Images of the gels stained with ethidium bromide were digitised with a digital video image analyser (The IMAGER ${ }^{\text {TM}}$; Appligene, Illkirch, France) and analysed with the NIH Image 1.54 program for the Macintosh. Results were expressed as the ratio of target gene over $\beta_{2}$ expression (relative expression, REx). PCR assays were performed at least in duplicate for each sample, and the results were averaged.

\section{Immunohistochemical studies}

The status of oestrogen and progesterone receptors, HER2 and p53 were determined by immunohistochemistry on paraffin-embedded sections $3 \mu \mathrm{m}$ thick. The antibodies, dilutions and antigen retrieval method used are detailed in Table 3. Immunostaining was performed with a Nexes automated immunostainer (Ventana, Illkirch, France). Sections were scored semiquantitatively by light microscopy by two pathologists. For oestrogen and progesterone receptors and p53, a threshold of $10 \%$ of stained nuclei was considered positive. For HER2, overexpression corresponded to more than $10 \%$ of cells showing complete membrane staining with high intensity. 
Table 1

Patient and tumour characteristics and relationship with HIF- $1 \alpha$, sHIF- $1 \alpha$ and aHIF mRNA expression concentration

\begin{tabular}{|c|c|c|c|c|c|c|c|c|}
\hline Parameter & Value & $n(\%)$ & HIF-1 & & sHIF-1 & & aHIF & \\
\hline \multirow[t]{2}{*}{ Age (years) } & $<50$ & $55(50)$ & $0.25 \pm 0.03$ & $P=0.66$ & $0.09 \pm 0.01$ & $P=0.53$ & $0.23 \pm 0.05$ & $P=0.66$ \\
\hline & $\geq 50$ & $55(50)$ & $0.22 \pm 0.03$ & & $0.11 \pm 0.02$ & & $0.24 \pm 0.04$ & \\
\hline \multirow[t]{4}{*}{ T stage } & 1 & $4(4)$ & $0.18 \pm 0.05$ & $P=0.49$ & $0.04 \pm 0.01$ & $P=0.30$ & $0.08 \pm 0.05$ & $P=0.010$ \\
\hline & 2 & $73(66)$ & $0.22 \pm 0.03$ & & $0.09 \pm 0.01$ & & $0.26 \pm 0.02$ & \\
\hline & 3 & $21(19)$ & $0.16 \pm 0.03$ & & $0.08 \pm 0.02$ & & $0.45 \pm 0.07$ & \\
\hline & 4 & $12(16)$ & $0.31 \pm 0.03$ & & $0.20 \pm 0.02$ & & $0.45 \pm 0.13$ & \\
\hline \multirow[t]{2}{*}{ Node status (clinical) } & - & $43(39)$ & $0.15 \pm 0.03$ & $P=0.036$ & $0.07 \pm 0.01$ & $P=0.11$ & $0.21 \pm 0.05$ & $P=0.20$ \\
\hline & + & $66(61)$ & $0.25 \pm 0.03$ & & $0.12 \pm 0.02$ & & $0.25 \pm 0.04$ & \\
\hline \multirow[t]{2}{*}{ Histological type } & IDC & $91(83)$ & $0.23 \pm 0.03$ & $P=0.006$ & $0.10 \pm 0.01$ & $P=0.74$ & $0.21 \pm 0.03$ & $P=0.38$ \\
\hline & ILC & $11(10)$ & $0.05 \pm 0.02$ & & $0.07 \pm 0.01$ & & $0.44 \pm 0.16$ & \\
\hline \multirow[t]{3}{*}{ SBR grade } & 1 & $13(15)$ & $0.24 \pm 0.07$ & $P=0.26$ & $0.12 \pm 0.04$ & $P=0.20$ & $0.31 \pm 0.14$ & $P=0.83$ \\
\hline & II & $44(50)$ & $0.26 \pm 0.04$ & & $0.12 \pm 0.02$ & & $0.20 \pm 0.04$ & \\
\hline & III & 31 (35) & $0.16 \pm 0.04$ & & $0.06 \pm 0.01$ & & $0.16 \pm 0.03$ & \\
\hline \multirow[t]{2}{*}{ S phase } & $<10 \%$ & $48(58)$ & $0.22 \pm 0.04$ & $P=0.40$ & $0.10 \pm 0.02$ & $P=0.97$ & $0.19 \pm 0.06$ & $P=0.018$ \\
\hline & $\geq 10 \%$ & $35(42)$ & $0.19 \pm 0.04$ & & $0.08 \pm 0.02$ & & $0.28 \pm 0.05$ & \\
\hline \multirow[t]{2}{*}{ Oestrogen receptors } & + & $51(56)$ & $0.17 \pm 0.03$ & $P=0.02$ & $0.09 \pm 0.02$ & $P=0.097$ & $0.23 \pm 0.05$ & $P=0.49$ \\
\hline & - & $40(44)$ & $0.29 \pm 0.04$ & & $0.12 \pm 0.02$ & & $0.22 \pm 0.05$ & \\
\hline \multirow[t]{2}{*}{ Progesterone receptors } & + & $24(26)$ & $0.18 \pm 0.04$ & $P=0.33$ & $0.09 \pm 0.02$ & $P=0.14$ & $0.26 \pm 0.09$ & $P=0.54$ \\
\hline & - & $67(74)$ & $0.24 \pm 0.03$ & & $0.11 \pm 0.01$ & & $0.22 \pm 0.04$ & \\
\hline \multirow[t]{2}{*}{ HER2 } & + & $18(21)$ & $0.29 \pm 0.06$ & $P=0.039$ & $0.13 \pm 0.03$ & $P=0.23$ & $0.19 \pm 0.07$ & $P=0.92$ \\
\hline & - & $66(79)$ & $0.17 \pm 0.03$ & & $0.08 \pm 0.01$ & & $0.23 \pm 0.05$ & \\
\hline \multirow[t]{2}{*}{ p53 } & $\leq 10 \%$ & $45(75)$ & $0.17 \pm 0.03$ & $P=0.20$ & $0.08 \pm 0.02$ & $P=0.48$ & $0.23 \pm 0.06$ & $P=0.37$ \\
\hline & $>10 \%$ & $15(25)$ & $0.22 \pm 0.04$ & & $0.07 \pm 0.01$ & & $0.21 \pm 0.07$ & \\
\hline
\end{tabular}

IDC, invasive ductal carcinoma; ILC, invasive lobular carcinoma; SBR, Scarff, Bloom and Richardson. For HIF-1, sHIF-1 and aHIF, results were expressed by relative expression (REx) as mean \pm standard error (SE). The final sums are not always equal to 110 patients because of some nonavailable data.

\section{Table 2}

\begin{tabular}{|c|c|c|c|}
\hline Oligonucleotide & Direction & Sequence & Product size \\
\hline \multirow[t]{2}{*}{ HIF- $1 \alpha$} & Forward & GTC GGA CAG CCT CAC CAA ACA GAG C & 486 bp and 359 bp if exon 14 missing \\
\hline & Reverse & GTT AAC TTG ATC CAA AGC TCT GAG & \\
\hline \multirow[t]{2}{*}{ aHIF } & Forward & TTT GTG TTT GAG CAT TTT AAT AGG C & $279 \mathrm{bp}$ \\
\hline & Reverse & CCA GGC CCC TTT GAT CAG CTT & \\
\hline \multirow[t]{2}{*}{$\beta_{2}$-microglobulin } & Forward & CAT CCA GCG TAC TCC AAA GA & $165 \mathrm{bp}$ \\
\hline & Reverse & GAC AAG TCT GAA TGC TCC AC & \\
\hline
\end{tabular}

\section{Statistics}

The $H$ test of Kruskal-Wallis was used to compare quantitative and categorical parameters. When two quantitative parameters were compared, Spearman's rank correlation test was used for abnormal distributions or unequal variances. Survival curves were designed with Kaplan-Meier's 
Table 3

\begin{tabular}{|c|c|c|c|c|c|}
\hline Antibody & Target & Source & Dilution & Antigen-retrieval method & Staining \\
\hline $6 \mathrm{~F} 11$ & Oestrogen receptor & Tébu (Le Perray en Yvelines, France) & $1: 40$ & Pressure cooker, 3 min, citrate buffer $\mathrm{pH} 7.3$ & Nuclear \\
\hline $1 \alpha 6$ & Progesterone receptor & Tébu (Le Perray en Yvelines, France) & $1: 30$ & Pressure cooker, 3 min, citrate buffer $\mathrm{pH} 7.3$ & Nuclear \\
\hline DA 485 & HER2 & Dako (Trappes, France) & $1: 1500$ & Water bath, 40 min, citrate buffer $\mathrm{pH} 6.0$ & Membrane \\
\hline DO7 & Wild-type and mutated p53 & Dako (Trappes, France) & $1: 200$ & Pressure cooker, 3 min, citrate buffer $\mathrm{pH} 7.3$ & Nuclear \\
\hline
\end{tabular}

method and compared with the log-rank test. We used the 5-year survival rate and Rothman's 95\% confidence interval to document survival. A Cox proportional-hazards model was used to investigate the simultaneous effect of biopathological parameters (giving a probability $(P)$ of less than 0.10 with univariate analysis) on survival. $P<0.05$ was considered significant. All tests were two-sided.

\section{Results}

\section{Expression of HIF-1 $\alpha$, sHIF- $1 \alpha$ and aHIF-1 $\alpha$}

REx values of HIF- $1 \alpha$, sHIF- $1 \alpha$ and aHIF in breast tumours were highly variable (Table 4). Expression of HIF-1 $\alpha$, sHIF- $1 \alpha$ and aHIF was detected in $85 \%, 86 \%$ and $72 \%$ of the tumours, respectively. Strong positive correlations between HIF- $1 \alpha$ and sHIF- $1 \alpha\left(P<10^{-7}\right)$ and sHIF- $1 \alpha$ and aHIF $\left(P<10^{-7}\right)$ were found (Fig. 1a, b). A weaker positive correlation was observed between HIF- $1 \alpha$ and aHIF $\left(P=4.3 \times 10^{-3} ;\right.$ Fig. $\left.1 \mathrm{c}\right)$. Finally, a strong inverse correlation between the HIF- $1 \alpha$ :sHIF- $1 \alpha$ ratio and aHIF was observed $\left(P<2.5 \times 10^{-4}\right.$; Fig. 1d).
Table 4

Repartition of HIF- $1 \alpha$, sHIF- $1 \alpha$ and aHIF relative expression in breast tumours

\begin{tabular}{lccc}
\hline Parameter & HIF-1 $\alpha$ & sHIF-1 $\alpha$ & aHIF \\
\hline Range & $0-0.97$ & $0-0.50$ & $0-1.98$ \\
Mean \pm SE & $0.21 \pm 0.02$ & $0.10 \pm 0.01$ & $0.23 \pm 0.03$ \\
Median & 0.10 & 0.06 & 0.09 \\
Interquartile interval & $0.03-0.35$ & $0.02-0.12$ & $0-0.35$ \\
\hline
\end{tabular}

\section{Relations between HIF- $1 \alpha$, sHIF- $1 \alpha$, aHIF-1 $\alpha$, patient and tumour characteristics}

The relationship between clinicopathological variables and each gene expression level are presented in Table 1. HIF-1 $\alpha$ was more highly expressed in node-positive tumours than in node-negative tumours and in tumours without oestrogen receptors $(P=0.02)$. We also observed

Figure 1

(a)

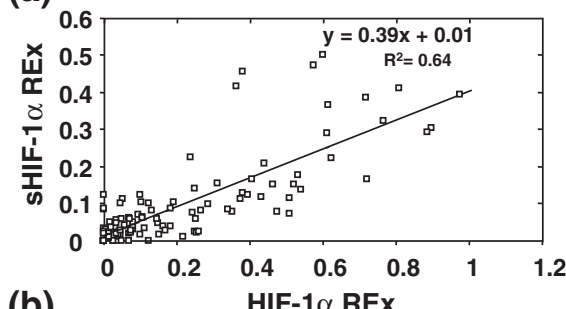

(b)

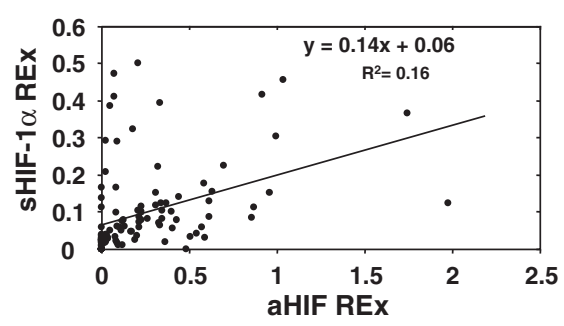

(c)

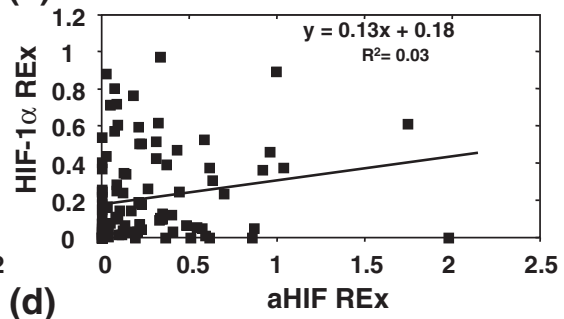

(d)

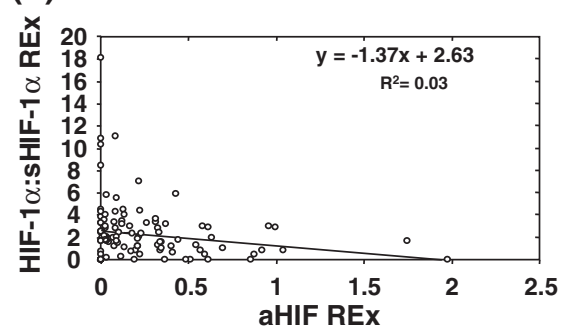

Association between relative expression (REx) values of HIF- $1 \alpha$, sHIF- $1 \alpha$ and aHIF. (a) Correlation between REx of sHIF- $1 \alpha$ and REx of HIF- $1 \alpha$ $\left(P<10^{-7}\right)$. (b) Correlation between REx of HIF- $1 \alpha$ and REx of aHIF $\left(P=4.3 \times 10^{-3}\right)$. (c) Correlation between REx of sHIF- $1 \alpha$ and REx of aHIF $\left(P<10^{-7}\right)$. (d) Negative correlation between HIF-1 $\alpha$ :sHIF-1 $\alpha$ ratio and aHIF REx $\left(P=2.5 \times 10^{-4}\right)$. 


\begin{tabular}{|c|c|c|c|c|c|c|c|}
\hline \multirow[b]{2}{*}{ Parameter } & \multirow[b]{2}{*}{ Value } & \multicolumn{3}{|c|}{ Univariate analysis } & \multicolumn{3}{|c|}{ Multivariate analysis (Cox) } \\
\hline & & $\mathrm{RR}$ & (Rothman's 95\% Cl) & $P$ & $\mathrm{RR}$ & $95 \% \mathrm{Cl}$ & $P$ \\
\hline \multirow[t]{2}{*}{ aHIF } & $R E x \leq 0.35$ & 1 & $80 \%(70-87)$ & 0.0038 & 1 & $1.5-7.4$ & 0.0016 \\
\hline & REx $>0.35$ & 2.8 & $45 \%(26-66)$ & & 3.3 & & \\
\hline \multirow[t]{3}{*}{ SBR grade } & 1 & 0 & $100 \%$ & 0.023 & 1 & $1.1-4.6$ & 0.0032 \\
\hline & 2 & 1 & $76 \%(62-87)$ & & 2.3 & $1.2-21.4$ & \\
\hline & 3 & 2 & $57 \%(39-73)$ & & 5.1 & & \\
\hline \multirow[t]{2}{*}{ Oestrogen receptors } & + & 1 & $82 \%(69-90)$ & 0.024 & 1 & $0.9-5.2$ & n.s. \\
\hline & - & 2.5 & $58 \%(42-72)$ & & 2.1 & & \\
\hline \multirow[t]{2}{*}{ S phase } & $\leq 10 \%$ & 1 & $81 \%(67-89)$ & 0.017 & 1 & $0.6-3.7$ & n.s. \\
\hline & $>10 \%$ & 2.6 & $56 \%(39-71)$ & & 1.5 & & \\
\hline
\end{tabular}

$\mathrm{Cl}$, confidence interval; n.s., not significant; REx, relative expression; RR, relative risk; SBR, Scarff, Bloom and Richardson.

a positive relation between HER2 and HIF-1 $\alpha(P=0.039)$. HIF-1 $\alpha$ transcript expression in invasive ductal carcinoma (IDC) was 4.5-fold that in invasive lobular carcinoma (ILC) $(P=0.006)$.

There was no relation between histological grade and either HIF-1 $\alpha$ or aHIF expression. No relation was seen between aHIF, clinical node status, histological type, oestrogen receptors, HER2 or p53. aHIF expression was higher in tumours of more than $5 \mathrm{~cm}$ (T3-T4) $(P=0.01)$ and in those with a high proliferation rate as measured by S phase $(P=0.018)$.

Given the large number of comparisons, a Bonferroni correction was performed for 30 comparisons (clinical variables with each transcript concentration), yielding $P=0.05 / 30=0.0017$. In this instance, none of the correlations maintained significance.

\section{Predictive value of HIF- $1 \alpha$, sHIF- $1 \alpha$ and aHIF- $1 \alpha$}

Pathological responses to neoadjuvant chemotherapy were followed after surgical resection (data not shown). None of HIF- $1 \alpha$, sHIF- $1 \alpha$ or aHIF was predictive of treatment response.

\section{Prognostic value of HIF-1 $\alpha$, sHIF- $1 \alpha$ and aHIF- $1 \alpha$}

At the time of analysis, 86 of 110 patients (78\%) were still alive, with a median follow-up of 61 months. As overall survival and disease-free survival (DFS) were similar, we compared gene expression with DFS. Neither HIF-1 $\alpha$ nor sHIF-1 $\alpha$ was related to survival in our series of breast cancer patients. A significant association $(P=0.0038)$ between aHIF expression and DFS was obtained when the three first quartiles were compared with the fourth one. The breakpoint between high and low aHIF expression was $\mathrm{REx}=0.35$, corresponding to the fourth quartile. The first quartile could not be tested with DFS because it contained only patients with null aHIF expression. The median (REx $=0.09$ ) was tested and did not reach significance $(P=0.059)$. The 5 -year survival rate was $80 \%$ in patients with low aHIF expression and $45 \%$ in patients with high aHIF expression. The death risk for patients with elevated aHIF transcript concentration was 2.8 -fold that in patients with a low concentration of HIF-1 $\alpha$ antisense. DFS was also significantly linked to oestrogen receptor status $(P=0.024)$, to SBR grade $(P=0.023)$ and to $S$ phase $(P=0.017)$ in univariate analyses. In multivariate analysis (Cox regression model), aHIF remained an independent prognostic marker $(P=0.0016)$, with SBR grade $(P=0.0032)$, as shown in Table 5 .

\section{Discussion}

HIF- $1 \alpha$ is frequently overexpressed in primary and metastatic human tumours [9]. In breast cancer, overexpression of HIF-1 $\alpha$ protein has been demonstrated in ductal in situ and invasive carcinomas $[9,10]$. We have recently reported the expression of aHIF transcript in breast tumours [5]. sHIF- $1 \alpha$ is expressed in several human cell lines and in human skin [3], but its expression in human tumours, especially in primary breast cancer, is still unknown.

In this study we examined 110 non-metastatic primary breast cancers for the presence of HIF- $1 \alpha$, sHIF- $1 \alpha$ and aHIF, and we studied their relationship with the clinical and biological behaviour and the prognosis of the tumours. 
The high number of routinely studied parameters (oestrogen and progesterone receptors, HER2 and p53) in addition to the small size of the biopsies did not allow us to test for the HIF- $1 \alpha$ protein in our breast cancer samples.

Although HIF- $1 \alpha$ and angiogenesis were closely linked [11], in this study we focused on HIF-1 $\alpha$ mRNA, its splicing variant and their potential regulation by aHIF. We did not evaluate angiogenesis because our 110 tumour samples were core needle biopsies, and in most cases the microvessel density could not be reliably assessed on a core needle biopsy specimen [12].

Few studies have assessed HIF-1 $\alpha$ in breast carcinoma. Our data indicate that $85 \%$ of breast tumours expressed HIF- $1 \alpha$ mRNA. Others have studied HIF- $1 \alpha$ in breast carcinoma by measuring protein expression by immunohistochemistry. Zhong and colleagues found that only $29 \%$ of primary breast carcinomas (15 of 52) expressed HIF- $1 \alpha$ protein, compared with $69 \%$ with lymph node metastasis [9], whereas Bos and colleagues reported that $80 \%$ of their invasive breast tumours (32 of 40 ) expressed HIF-1 $\alpha$ protein [10]. At the mRNA level, HIF-1 $\alpha$ was detected in $71.7 \%$ of ovarian carcinomas (43 of 60 ) [13] and $100 \%$ of glioblastomas (34 of 34) [14].

We established a negative relationship between HIF- $1 \alpha$ mRNA and oestrogen receptors. Such a relationship has also been found between HIF-1 $\alpha$ protein and oestrogen receptors in cultured breast cell lines [15], even though Bos and colleagues reported contradictory results [10]. An inverse correlation was reported between oestrogen receptors and HIF-1 $\beta$ splicing variant in breast carcinoma [16], but we did not observe such an association with sHIF- $1 \alpha$.

In our study we demonstrated a positive relation between HER2 and HIF-1 $\alpha$ mRNA concentrations. A previous study, performed on cultured cell lines, also found such a correlation with HIF- $1 \alpha$ protein, signifying that HER2 was involved in promoting HIF-1 $\alpha$ protein synthesis [17]. Another study showed a borderline association between HIF- $1 \alpha$ protein concentration and HER2 expression [10].

We found that HIF- $1 \alpha$ mRNA expression in IDC was 4.5-fold that in ILC, and that $91 \%$ of ILC had no more than $1 \%$ relative HIF- $1 \alpha$ mRNA expression. This is in accordance with a recent study on $\left[{ }^{18} \mathrm{~F}\right]$ fluorodeoxyglucose uptake in human breast cancer, in which $86 \%$ of ILC had no more than $1 \%$ HIF- $1 \alpha$ protein [18].

We did not establish any relation between HIF- $1 \alpha$ mRNA expression and prognosis in breast cancer, as described in the few reports that studied HIF- $1 \alpha$ at the mRNA level in ovarian carcinomas and glioblastomas $[13,14]$. On the tochemistry have reported significantly poor prognosis in head and neck and oropharyngeal carcinoma, in early stage invasive cervical cancer, and in oligodendrogliomas [19] (reviewed in [6]).

Because sHIF- $1 \alpha$ encodes a shorter HIF- $1 \alpha$ protein able to interact with HIF-1 $\beta$, thus forming a low-activity transcription factor [3], one might expect that high concentrations of sHIF- $1 \alpha$ mRNA would be associated with a good prognosis and a less aggressive tumour phenotype. This was not observed in our study, even though among the 14 patients exhibiting the highest sHIF- $1 \alpha$ REx (more than 0.29 ) only $1(7 \%)$ died during the study period.

A unique aspect of our work was to measure the expression of aHIF transcript together with HIF- $1 \alpha$ and sHIF- $1 \alpha$ in the same amplification reaction. The prognostic value of HIF-1 $\alpha$ mRNA was not observed in our series of 110 human breast cancers. However, we found that aHIF seemed to be a strong independent prognostic marker in this series. Moreover, aHIF expression was associated with T3-T4 tumours and an S phase of more than $10 \%$. However, how aHIF expression interferes with HIF-1 $\alpha$ expression remains to be explained.

According to our observations, aHIF could be involved in the regulation of HIF- $1 \alpha$ mRNA expression at a post-transcriptional level. Indeed, there is a strong negative association $\left(P<2.5 \times 10^{-4}\right)$ between the ratio HIF-1 $\alpha$ :sHIF-1 $\alpha$ and aHIF REx (Fig. 1d). This might indicate that the greater the amount of aHIF transcript present, the more HIF- $1 \alpha$ mRNA is spliced. Consequently, a smaller amount of fulllength HIF- $1 \alpha$ mRNA is present. Another interpretation based on previous results [5] would be that aHIF could specifically destabilise HIF- $1 \alpha$ mRNA but not sHIF- $1 \alpha$ transcript, resulting in larger amounts of the spliced form for elevated amounts of aHIF.

The first significant study of HIF- $1 \alpha$ protein concentrations in cancer cells was published in 1999 [9]. Although the correlation between HIF- $1 \alpha$ overexpression and poor clinical outcome is not systematic (reviewed in [6]), many other studies both in humans and in animals have revealed a direct involvement of HIF- $1 \alpha$ in tumour progression $[10,20]$.

To consider HIF- $1 \alpha$ as the unique parameter to be measured might be too reductionist. Indeed, it seems obvious that other factors are involved in tumour progression or resistance to treatments. If we focus on HIF- $1 \alpha$, HIF- $1 \alpha$ mRNA splicing variants have been shown to encode shorter forms of HIF-1 $\alpha$ that could compete with the normal full-length protein [3]. Until now, HIF-1 $\alpha$ detection has been done essentially with immunohistochemistry, with the use of antibodies that recognise either all forms of the protein or only the full-length form of the protein. 
Figure 2

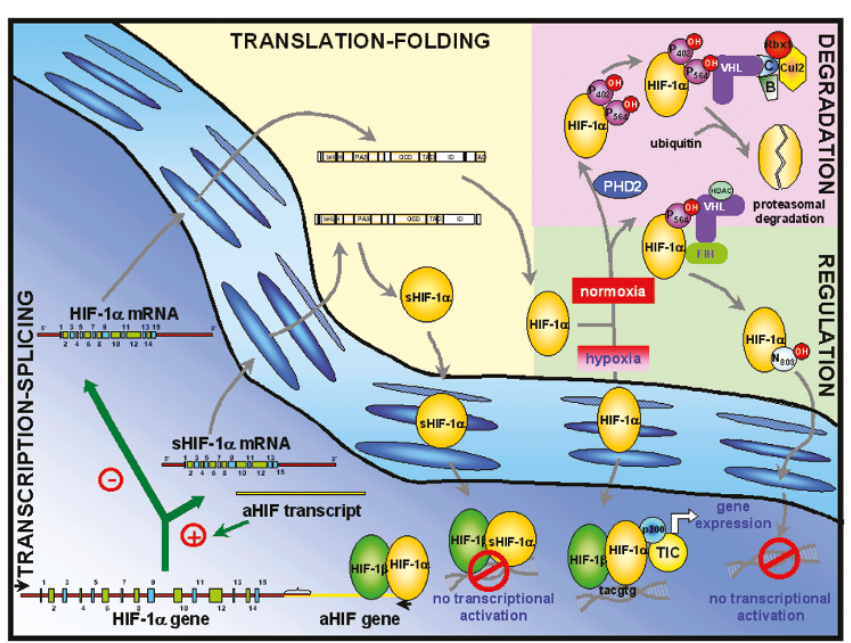

Scheme of post-transcriptional and post-translational regulation of $\mathrm{HIF}-1 \alpha$.

Immunohistochemistry might be better performed with both types of antibody, to discriminate the full-length protein from its shorter forms, which are apparently much less deleterious. Thus, discriminating immunological tools should be designed and made available.

Only a few studies with RT-PCR have been performed to link HIF-1 $\alpha$ mRNA expression and tumour-specific parameters $[13,14]$, which is surprising because this kind of study is able to discriminate between the different splicing variants of HIF- $1 \alpha$, even though it does not indicate the presence of the protein.

Finally, detection of a protein does not indicate whether this protein is active. Indeed, a protein inhibitor of HIF- $1 \alpha$ has recently been described and identified as the asparagine hydroxylase known to block the interaction between p300 and HIF-1 [21]. One could therefore imagine that large amounts of this protein could easily inhibit large amounts of HIF- $1 \alpha$.

\section{Conclusion}

This work shows that aHIF is a poor prognosis marker in breast cancer. It seems to participate in HIF- $1 \alpha$ mRNA regulation, perhaps by affecting the amount of the spliced form (see Fig. 2 for a summary). HIF-1 $\alpha$ is part of a transcription factor controlling the expression of more than 50 target genes whose products have crucial functions in tumour progression, angiogenesis, the maintenance of ATP production in cells, anti-apoptosis, and so on. Changes in its regulation will therefore have consequences for each of the above processes. In this time of targeted therapeutics for breast cancer (anti-HER2, antiangiogenesis), it seems promising to study the regulation of a factor governing such targets.

\section{Competing interests}

None declared.

\section{Acknowledgements}

We thank Christiane Jullien for her excellent technical assistance with the immunostaining.

\section{References}

1. Semenza GL: Hypoxia-inducible factor 1: oxygen homeostasis and disease pathophysiology. Trends Mol Med 2001, 7:345350.

2. Page EL, Robitaille GA, Pouyssegur J, Richard DE: Induction of hypoxia-inducible factor- $1 \alpha$ by transcriptional and translational mechanisms. J Biol Chem 2002, 277:48403-48409.

3. Gothié E, Richard DE, Berra E, Pages G, Pouyssegur J: Identification of alternative spliced variants of human hypoxiainducible factor-1 $\alpha$. J Biol Chem 2000, 275:6922-6927.

4. Thrash-Bingham CA, Tartof KD: aHIF: a natural antisense transcript overexpressed in human renal cancer and during hypoxia. J Natl Cancer Inst 1999, 91:143-151.

5. Rossignol F, Vaché C, Clottes E: Natural antisense transcripts of hypoxia-inducible factor-1alpha are detected in different normal and tumour human tissues. Gene 2002, 299:135-140.

6. L'Allemain G: The hypoxia-inducible factor HIF as a new target in cancer research. Bull Cancer 2002, 89:257-260.

7. Sobin LH, Wittekind CH: UICC - TNM classification of malignant tumours. 5th edition. New York: Wiley-Liss; 1998.

8. Elston EW, Ellis JO: Methods for grading breast cancer. J Clin Pathol 1993, 46:189-190.

9. Zhong H, De Marzo AM, Laughner E, Lim M, Hilton DA, Zagzag D Buechler P, Isaacs WB, Semenza Gl, Simons JW: Overexpression of hypoxia-inducible factor $1 \alpha$ in common human cancers and their metastases. Cancer Res 1999, 59:58305835 .

10. Bos R, Zhong $\mathrm{H}$, Hanrahan $\mathrm{CH}$, Mommers ECM, Semenza GL, Pinedo Abeloff MD, Simons JW, van Diest PJ, van der Wall E: Levels of hypoxia-inducible factor- $1 \alpha$ during breast carcinogenesis. J Natl Cancer Inst 2001, 93:309-314.

11. Semenza GL: HIF-1: using two hands to flip the angiogenic switch. Cancer Metastasis Rev 2000, 19:59-65.

12. Jacobs TW, Siziopikou KP, Prioleau JE, Raza S, Baum JK, Hayes DF, Schnitt SJ: Do prognostic marker studies on core needle biopsy specimens of breast carcinoma accurately reflect the marker status of the tumor? Mod Pathol 1998, 11:259-264

13. Nakayama $K$, Kanzaki A, Hata K, Katabuchi $H$, Okamura $H$, Miyazaki K, Fukumoto M, Takebayashi Y: Hypoxia-inducible factor 1 alpha (HIF-1 $\alpha$ ) gene expression in human ovarian carcinoma. Cancer Lett 2002, 176:215-223.

14. Sondergaard KL, Hilton DA, Penney M, Ollerenshaw M, Demaine $A G$ : Expression of hypoxia-inducible factor $1 \alpha$ in tumours of patients with glioblastoma. Neuropath Appl Neurobiol 2002, 28:210-217.

15. Kurebayashi J, Otsuki T, Moriya T, Sonoo H: Hypoxia reduces hormone responsiveness of human breast cancer cells. Jpn J Cancer Res 2001, 92:1093-1101.

16. Qin C, Wilson C, Blancher C, Taylor M, Safe S, Harris AL: Association of ARNT splice variants with estrogen receptor-negative breast cancer, poor induction of vascular endothelial growth factor under hypoxia, and poor prognosis. Clin Cancer Res. 2001, 7:818-823.

17. Laughner E, Taghavi P, Chiles K, Mahon PC, Semenza GL: HER2 (neu) signaling increases the rate of hypoxia-inducible factor 1alpha (HIF-1alpha) synthesis: novel mechanism for HIF-1mediated vascular endothelial growth factor expression. Mol Cell Biol 2001, 21:3995-4004.

18. Bos R, van der Hoeven JJM, van der Wall E, van der Groep P, van Diest PJ, Comans EF Joshi U, Semenza GL, Hoekstra OS, Lammertsma AA, Molthoff CF: Biologic correlates of ${ }^{18}$ Fluorodeoxyglucose uptake in human breast cancer measured by positron emission tomography. J Clin Oncol 2002, 20:379-387.

19. Beasley NJ, Leek R, Alam M, Turley H, Cox GJ, Gatter K Millard P, Fuggle S, Harris AL: Hypoxia-inducible factors HIF-1 $\alpha$ and HIF$2 \alpha$ in head and neck cancer: relationship to tumor biology and treatment outcome in surgically resected patients. Cancer Res 2002, 62:2493-2497. 
Breast Cancer Research Vol 5 No 6 Cayre et al.

20. Elson DA, Ryan HE, Snow JW, Johnson R, Arbeit JM: Coordinate up-regulation of hypoxia inducible factor (HIF)- $1 \alpha$ and HIF-1 target genes during multistage epidermal carcinogenesis and wound healing. Cancer Res 2000, 60:6189-6195.

21. Lando D, Peet DJ, Gorman JJ, Whelan DA, Whitelaw ML, Bruick RK: FIH-1 is an asparaginyl hydroxylase enzyme that regulates the transcriptional activity of hypoxia-inducible factor. Genes Dev 2002, 16:1466-1471.

\section{Correspondence}

Anne Cayre, Department of Pathology, Centre Jean Perrin, BP 392, 63011 Clermont-Ferrand Cedex, France. Tel: +33 4732781 67; fax: +33 4732781 80; e-mail: anne.CAYRE@cjp.fr 